\title{
Growth and leaf morphology of hazelnut cultivars grown under semi-controlled conditions
}

\author{
J. Toillon ${ }^{1}$, A. Paradinas ${ }^{1}$ and M. Thomas ${ }^{2}$ \\ ${ }^{1}$ Association Nationale des Producteurs de Noisettes (ANPN), Louberie, Cancon, France \\ ${ }^{2}$ SCA Unicoque, Louberie, Cancon, France
}

\section{Summary}

To be competitive, the French hazelnut growers need to evaluate new hazelnut cultivars and their adaptability to contrasting environments in terms of water and mineral resources. The ability to use resources efficiently, including water (i.e., water use efficiency, WUE) can be studied at different levels such as at foliar level. To study WUE, it is necessary to standardise the measurement of the leaf position on the stem and to work on the first mature leaf of a fully illuminated branch. The objectives of this study were (i) to assess the variability of eight hazelnut cultivars as to their leaf morphology and physiology (first mature leaf), and biomass production; (ii) to compare these varieties to one another on the tested traits; and (iii) to assess the relationships between the different traits. Eight hazelnut cultivars were conducted for two months in a cold greenhouse under semi-controlled conditions. The first mature leaf was determined and was located at the seventh leaf position after the first leaf measuring more than $20 \mathrm{~mm}$ below the apex. Two reference cultivars ('Corabel ${ }^{\circledR '}$ and 'Pauetet') showed significantly larger trunk diameters and 'Corabel ${ }^{\circledR '}$ cultivar had noticeably more woody and foliar biomass and roots than 'Sacajawea' cultivar. This data showed the higher vigour of the 'Corabel ${ }^{\circledR}$ ' reference. Strong correlations between physiological, and foliar morphological traits, and among biomass traits, were observed. No strong correlations were evidenced between foliar and biomass traits. This study will provide the opportunity to standardise samples for cultivar comparisons as their water-use efficiency, and help classify hazelnut cultivars.

\section{Keywords}

Corylus avellana L., Filbert, leaf morphology, leaf physiology, foliar index, leaf plastochron index, specific leaf area, first mature leaf

\section{Introduction}

Hazelnuts are native to the temperate zones of the northern hemisphere. Hazelnuts belong to the family Betulaceae, subfamily Coryloideae, genus Corylus L. Around the world, a wide range of hazelnuts (Corylus avellana L.) can be observed divided into 9 to 25 species according to the taxonomic authority (Botta et al., 2019; Germain and Sarraquigne, 2004). The cultivated hazelnuts mainly originate from C. avellana L., C. americana Marshall, C. heterophylla Fisher,

\section{Significance of this study}

What is already known on this subject?

- The position of the first mature leaf has been determined in fast-growing tree species, but it is still unknown for hazelnut trees.

What are the new findings?

- The position of the first mature leaf was determined; this leaf is the seventh leaf from the first leaf just exceeding $20 \mathrm{~mm}$ below the apex.

What is the expected impact on horticulture?

- This finding will allow to standardise leaf samples for physiological analyses and help to compare data among papers.

and C. maxima Mill. (Anil et al., 2016; Botta et al., 2019). These species have variable morphological and physiological characteristics in terms of tree architecture, fruit and leaf shape (round to oval, toothed to smooth) and colour (pink, purple, yellow, green) (Bergougnoux et al., 1978; Germain and Sarraquigne, 2004; Mehlenbacher and Smith, 1995; Mehlenbacher et al., 2018). In 2018, the hazelnut world production was 863,888 tons, produced on 966,196 ha (world mean yield of 0.894 tha $^{-1}$ ) (Food and Agriculture Organisation of the United Nations, 2020). This data could vary among nations. Indeed, in 2018, the Turkish production was 515,000 t (ca. $60 \%$ of the world production), for 728,381 ha $(75 \%$ of world hazelnut orchards), resulting in $0,707 \mathrm{t} \mathrm{ha}^{-1} ; 132,699 \mathrm{t}$ for 78,593 ha in Italy $\left(1,688 \mathrm{t} \mathrm{ha}^{-1}\right) ; 46,270 \mathrm{t}$ for 17,806 ha in the United States of America (2,598 $\left.\mathrm{t} \mathrm{ha}^{-1}\right)$; and, 14,988 $\mathrm{t}$ for 6,644 ha in France (2,256 t ha-1) (Food and Agriculture Organisation of the United Nations, 2020). The French hazelnut orchards are among the most productive in the world, with the U.S. orchards. In France, hazelnut orchards are irrigated during the growing season, more especially during the fruit development. Up to now, water supplies have not been calculated based on the cultivars needs but according to the plantation area. The plant needs can be assessed at leaf level uptake on a branch, using a Scholander pressure bomb (Hammel, 1968; Scholander et al., 1964, 1965; Tyree and Hammel, 1972). Another way is to evaluate the ability of plants to produce biomass (dry matter or crop yield) per water quantity consumed in evapotranspiration, i.e., the wateruse efficiency (WUE) of the plant (Begg and Turner, 1976; Pallardy, 2008). At physiological level, WUE is calculated as the ratio between Net $\mathrm{CO}_{2}$ uptake and transpiration rate at the whole plant level (WUE) (Fischer and Turner, 1978), and at the leaf level (WUE $E_{\mathrm{i}}$, Intrinsic Water-use Efficiency) 
(Farquhar et al., 1980; Schulze and Küppers, 1979). The leaf level, which is used to measure gas exchanges, needs to be standardised and have repeatability among studies. Authors specified their leaf sample as a fully illuminated leaf, but noone has clearly identified the leaf level uptake (Catoni et al., 2015; Pasqualotto et al., 2018; Valentini et al., 2009). Up to now, and to our knowledge, the position of the first mature leaf on a growing branch of a hazelnut tree has never been determined. The first mature leaf is the first leaf which has a carbon balance beneficial to the tree; that this, the first mature leaf is the first leaf which can produce more organic compounds than it will consume. Indeed, the physiology of leaves may vary depending on the stage of leaf development. As observed in several studies, juvenile, mature or senescent leaves do not have the same morphology and physiology (Bertamini and Nedunchezhian, 2002; Ishida et al., 2005). Our study aims to determine the position of the first mature leaf in various hazelnut cultivars. The objective of this study is (i) to assess the variability of six cultivars and two references for their leaf morphology and physiology (first mature leaf), and biomass production; (ii) to compare these varieties on the tested traits; and (iii) to assess the relationships between the different traits.

\section{Material and methods}

\section{Plant material, experimental design, and growth conditions}

Ten randomised complete blocks of eight hazelnut cultivars were set in a cold greenhouse on March 11 $11^{\text {th }}, 2019$, in Cancon, Southwest of France (44.542475N, 0.593661E). Each block was composed of one sample of each cultivar. Six out of the eight cultivars studied ('Ennis', 'Jefferson', 'Sacajawea', 'Santiam', 'Tonda Pacifica', and 'Yamhill') are from Oregon State University (OSU) breeding program (Lagerstedt, 1980; Mehlenbacher et al., 2007, 2008, 2009, 2011a, b). The two

TABLE 1. Description and dates of studied traits.

\begin{tabular}{|c|c|c|c|c|}
\hline Studied traits & Unit & Abbreviation & $\begin{array}{c}\text { Number of } \\
\text { monitored plants }\end{array}$ & Timing \\
\hline \multicolumn{5}{|l|}{ From March $13^{\text {th }}$ to May $29^{\text {th }}$} \\
\hline \multicolumn{5}{|l|}{ Growth traits } \\
\hline Basal trunk diameter & $\mathrm{mm}$ & & 40 & Weekly \\
\hline \multicolumn{5}{|l|}{ From March $27^{\text {th }}$ to May $29^{\text {th }}$} \\
\hline \multicolumn{5}{|l|}{ Growth traits } \\
\hline Basal diameter of the longest stem & $\mathrm{mm}$ & & 40 & Weekly \\
\hline Length of the longest stem & $\mathrm{cm}$ & & 40 & Weekly \\
\hline Length of the highest stem under the cutting point & $\mathrm{cm}$ & & 40 & Weekly \\
\hline \multicolumn{5}{|l|}{ May $29^{\text {th }}$} \\
\hline \multicolumn{5}{|l|}{ Leaf traits } \\
\hline Leaf position & From 1 to $n$ from apex & & 80 & \\
\hline Fresh weight & g & LeafFM & 80 & \\
\hline Dry weight & g & LeafDM & 80 & \\
\hline Total leaves dry weight of the collected stem & $g$ & & 80 & \\
\hline Lamina length & $\mathrm{mm}$ & LL & 80 & \\
\hline Lamina width & $\mathrm{mm}$ & LW & 80 & \\
\hline Leaf area & $\mathrm{cm}^{2}$ & $\mathrm{LA}$ & 80 & \\
\hline Specific leaf area & $\mathrm{cm}^{2} \mathrm{~g}_{\mathrm{DM}}{ }^{-1}$ & SLA & 80 & \\
\hline Leaf Plastochron index & & LPI & 80 & \\
\hline \multicolumn{5}{|l|}{ From March $27^{\text {th }}$ to July $23^{\text {rd }}$} \\
\hline \multicolumn{5}{|l|}{ Growth traits } \\
\hline Basal trunk diameter & $\mathrm{mm}$ & & 40 & Weekly \\
\hline Length of the longest stem & $\mathrm{cm}$ & & 40 & Weekly \\
\hline Lamina length & $\mathrm{mm}$ & $\mathrm{LL}$ & 40 & Weekly \\
\hline \multicolumn{5}{|l|}{ July $23^{\text {rd }}$} \\
\hline \multicolumn{5}{|l|}{ First mature leave traits } \\
\hline Fresh weight & $g$ & LeafFM & 40 & \\
\hline Dry weight & $g$ & LeafDM & 40 & \\
\hline Lamina length & $\mathrm{mm}$ & LL & 40 & \\
\hline Lamina width & $\mathrm{mm}$ & $\mathrm{LW}$ & 40 & \\
\hline Leaf area & $\mathrm{cm}^{2}$ & LA & 40 & \\
\hline Specific leaf area & $\mathrm{cm}^{2} \mathrm{~g}_{\mathrm{DM}}^{-1}$ & SLA & 40 & \\
\hline \multicolumn{5}{|l|}{ Biomass traits } \\
\hline Total leaves dry weight & $g$ & & 40 & \\
\hline Total stem dry weight & $g$ & & 40 & \\
\hline Total trunk dry weight & $g$ & & 40 & \\
\hline Total roots dry weight & $g$ & & 40 & \\
\hline
\end{tabular}




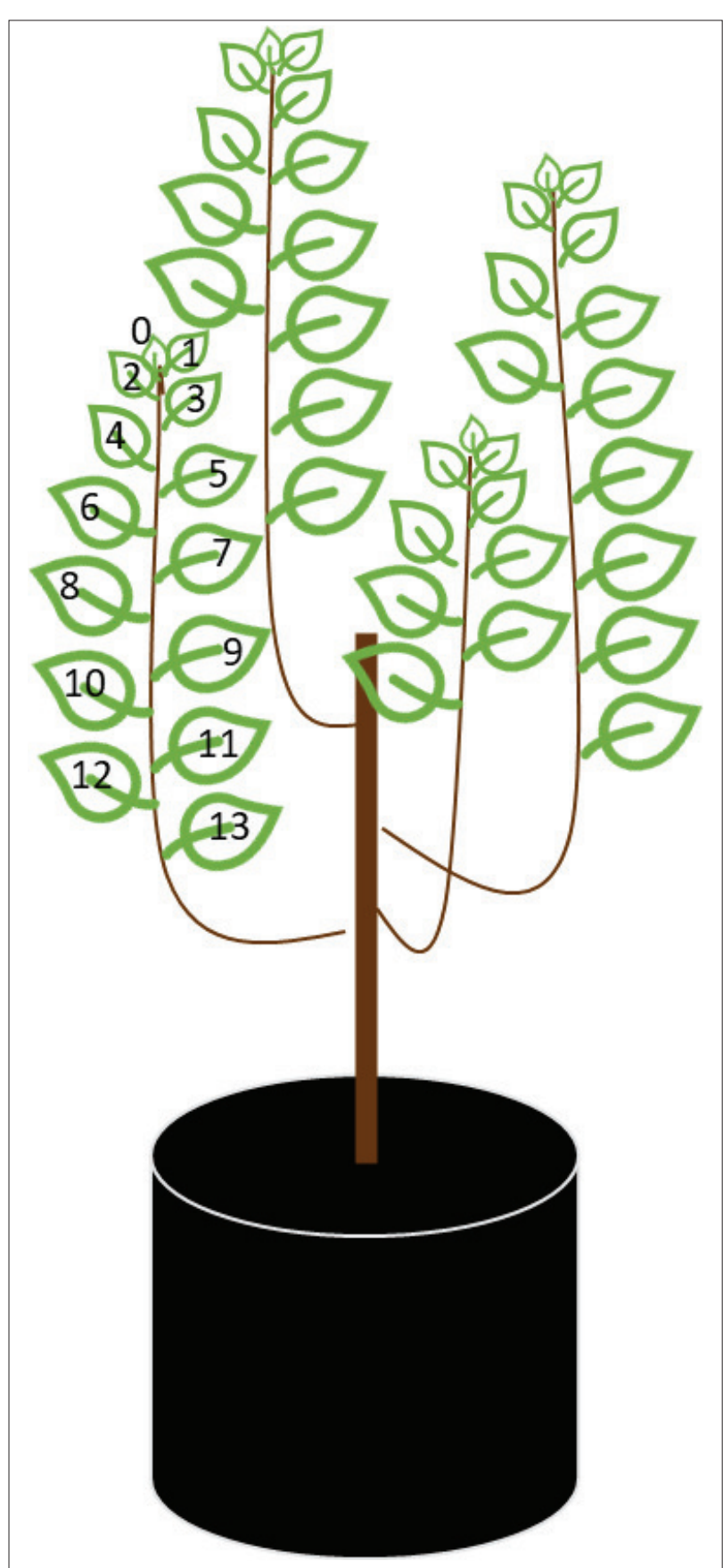

FIGURE 1. Numbering of the position of leaves on the branch. Number ' 1 ' indicates the leaf just exceeding $20 \mathrm{~mm}$ length below the apex.

other cultivars are commonly grown in France and they were used as internal test-plants for the experiment: 'Pauetet' and 'Corabel ${ }^{\circledR '}$ cultivars (Germain and Sarraquigne, 2004). 'Ennis', 'Jefferson', 'Sacajawea', 'Santiam', 'Tonda Pacifica', 'Yamhill', and 'Corabel ${ }^{\circledR '}$ cultivars were produced in vitro while 'Pauetet' cultivar was issued from root cuttings.

Each tree was planted in $5 \mathrm{~L}$ pots with loam $(63 \%$ organic matter, $\mathrm{pH}-\mathrm{H}_{2} \mathrm{O} 6.5,160 \mathrm{~g} \mathrm{~m}^{-3} \mathrm{~N}, 80 \mathrm{~g} \mathrm{~m}^{-3} \mathrm{P}_{2} \mathrm{O}_{5}$ ) and $20 \mathrm{~g}$ of a slow degradation chemical fertiliser $\left(4 \% \mathrm{~N}, 7 \% \mathrm{P}_{2} \mathrm{O}_{5}, 7 \% \mathrm{~K}_{2} \mathrm{O}\right.$ and $2 \% \mathrm{MgO}$ ). Each tree was cut at $40 \mathrm{~cm}$ stem length. Each tree was irrigated with a drip adjusted according to the plant's needs. All necessary interventions for plant management (pest control and irrigation) were carried out on the pots during the experiment. The temperature and the relative humidity of the greenhouse were monitored using a data logger (Tinytag, TGP-4017, Gemini Data Logger) during the time of the experiment. In the greenhouse, the temperature ranged from $16.35^{\circ} \mathrm{C}$ in March to $30.08^{\circ} \mathrm{C}$ in July. The humidity was relatively stable and oscillated between $68 \%$ and $76 \%$. Table 1 shows dates and measurements which were carried out during the experiment.

\section{First experiment: Evaluation of the leaf plastochron index and determination of the first mature leaf}

In this experiment, all measurements have been carried out on 40 trees (i.e., 8 cultivars $\times 5$ blocks). The experiment began on March $13^{\text {th }}, 2019$ with growth measurements and ended on May $27^{\text {th }}, 2019$, i.e., 11 weeks after the starting of the experiment.

1. Growth kinetics of the plants. From the beginning of the experiment, the stem diameter was measured weekly, $5 \mathrm{~cm}$ above the loam, using a digital caliper (Mahr, MahrCal 16EWR). Once the growth of the first stem inserted below the cutting point began, the length $(\mathrm{cm})$ of the stem was monitored weekly for the 40 trees monitored, until the end of the experiment. The selected stem was chosen to standardise the level of stem measurement among trees.

2. Morphological and physiological leaf characteristics. The longest stem of each tree was selected, and its length $(\mathrm{cm})$ and basal diameter $(\mathrm{mm})$ were measured. This stem was defoliated on May 29 $9^{\text {th }}, 2019$ and collected leaves were individually packed with their number of leaf position on the stem (from 1 to $\mathrm{n}$ ). The numbering began from the apex; Leaf number 1 was the first leaf just exceeding $20 \mathrm{~mm}$ of lamina length (Figure 1). Leaf area (LA, $\left.\mathrm{cm}^{2}\right)$, lamina length without petiole ( $\mathrm{LL}, \mathrm{mm}$ ), and lamina width ( $\mathrm{LW}, \mathrm{mm}$ ) were collected using a Li-Cor area meter (Li-Cor 3000 CAP package). Fresh leaves were weighed (LeafFM, g) and dried at $65^{\circ} \mathrm{C}$ in a drying oven for $48 \mathrm{~h}$. The dried leaves were finally weighed (LeafDM, g). The specific leaf area (SLA) was calculated as the ratio between leaf area and leaf dry mass $\left(\mathrm{cm}^{2}\right.$ $\left.\mathrm{g}_{\mathrm{DM}}{ }^{-1}\right)$. LPI was calculated using the following formula:

$$
L P I=(n+(\log L n-\log 20)) /(\log L n-\log L n+1)
$$

in which $n$ stands for the leaf level uptake, $L n$ the lamina length of the leaf $n(\mathrm{~mm})$, and $\log 20$ the first leaf exceeding $20 \mathrm{~mm}$ (Erickson and Michelini, 1957). LPI has been used to measure the time between the initiation of two successive leaf primordia (Ade-Ademilua et al., 2005).

3. Determination of the first mature leaf. To determine the first mature leaf, SLA values were plotted with LPI values. The first mature leaf was located on the graph where SLA was maximal and stable. This method has already been used in other woody species, such as Populus sp. (Marron et al., 2005).

\section{Second experiment: Foliar growth kinetic and biomass partitioning}

1. Growth kinetics of the plants. The basal diameter, at $5 \mathrm{~cm}$ above the pot, and the length of the longest stem, were monitored weekly, from March $27^{\text {th }}$ to July $23^{\text {th }}, 2019$, for five trees per cultivars (i.e., $n=40$ trees). Length without petiole, and width of each lamina leaf of the longest stem, were monitored weekly for seven weeks to evaluate the kinetic leaf growth.

2. Biomass partitioning of plants compartments. All trees were separated into four compartments. The belowground compartment corresponded to the root system, and the above-ground biomass was divided into three compart- 


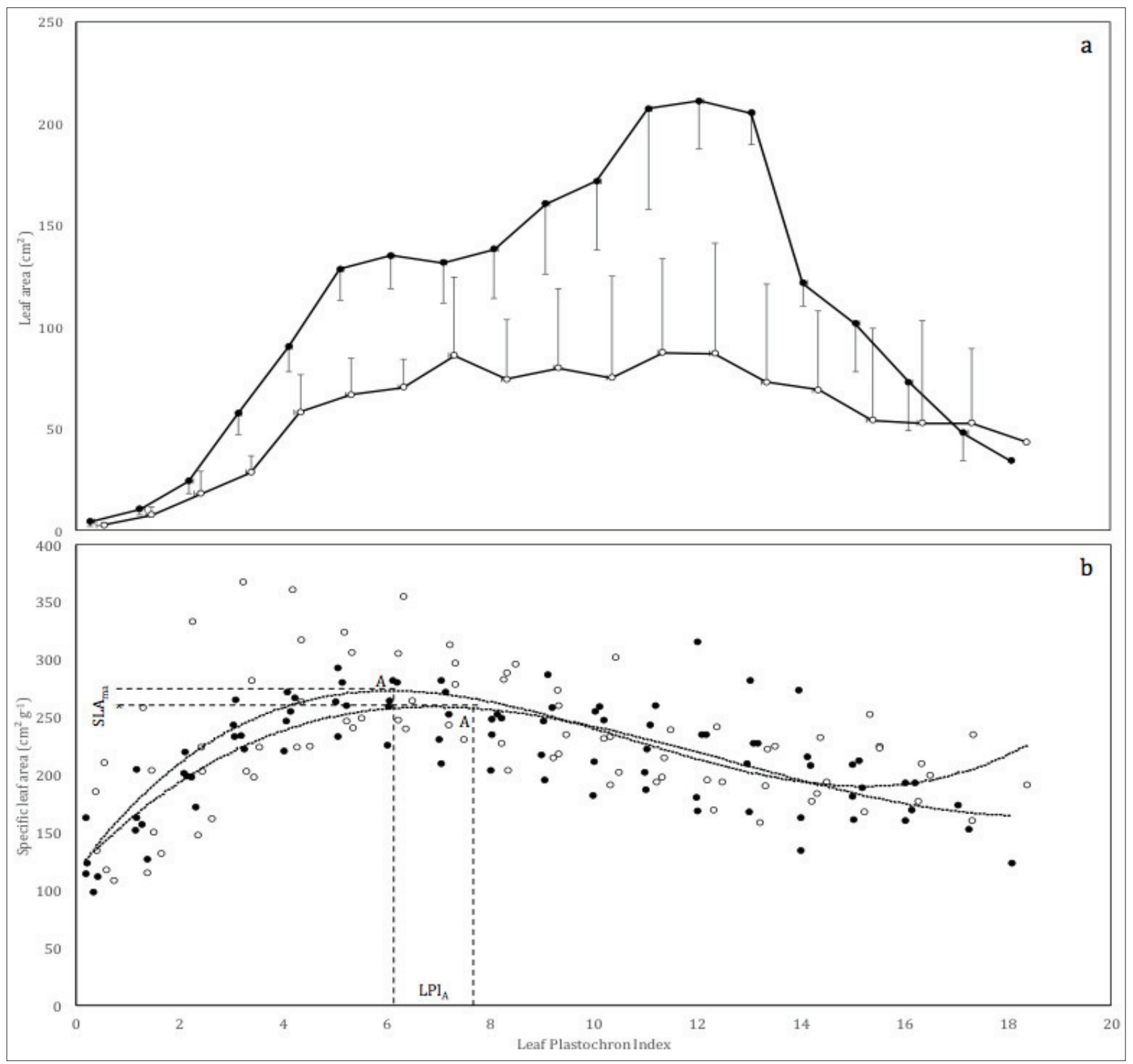

FIGURE 2. Relationships between leaf plastochron index (LPI), leaf area (LA) (a) and specific leaf area (SLA) (b). Means are presented with their standard error. These relationships were established for all cultivars. Here, they are presented for 'Corabel ${ }^{\circledR \prime}(\bigcirc)$ and 'Pauetet' $(\bigcirc)$ cultivars. Abbreviations: $\mathrm{SLA}_{\max }=$ maximal specific leaf area; $\mathrm{LPI}_{\mathrm{A}}=$ LPI for leaf with maximal SLA.

ments: the trunk biomass, the stem biomass, and the foliar biomass. All compartments were individualised for each tree, fresh weighed, dried in a drying oven at $65^{\circ} \mathrm{C}$ during $48 \mathrm{~h}$ and weighed anew. The dry biomass of each compartment was expressed as the percentage of total plant biomass for each compartment.

3. Leaf morphology. At the end of the experiment, the first mature leaf (determined few weeks before) was sampled. The leaf fresh weight, leaf length, LA and leaf dry mass were measured for each collected mature leaf.

\section{Statistical analysis}

Results were analysed with the R software (R Core Team, 2019). The R Packages 'ade4', 'agricolae', 'factoextra', 'FactoMineR', and 'MASS' were used to analyse the data set (Bougeard and Dray, 2018; Chessel et al., 2004; Dray et al., 2007; Kassambara and Mundt, 2017; Lê et al., 2008; Mendiburu, 2010; Venables and Ripley, 2002). Data was tested to meet the assumptions of homoscedasticity and the normality distribution of residuals. Statistic tests were considered significant at $P \leq 0.05$. Means are presented with their standard error. The following ANOVA model was run to individual data:

$$
Y_{i j}=\mu+B_{i}+G_{j}+\varepsilon_{i j}
$$

where $Y_{i j}$ refers to the tested variables, $\mu$ to the grand mean of the tested variables, $B_{i}$ to the effect of the block I considered as fixed, $G_{j}$ to the effect of the genotype $j$ considered as random, and $\varepsilon_{i j}$ to the residual value of the model.

When these assumptions were not found, a KruskalWallis test was run. The following model was used to individual data:

$$
K W=\frac{12}{N(N+1)} \sum_{i=1}^{K} n_{i}\left(R-R_{i}\right)^{2}
$$

in which $K W$ refers to the Kruskal-Wallis test statistics, $N$ to the sum of all observations, $n$ to the total number of observa- 
근

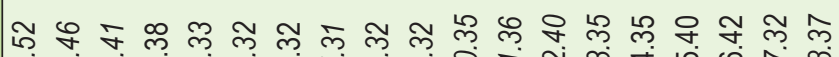

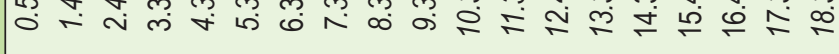
(1)

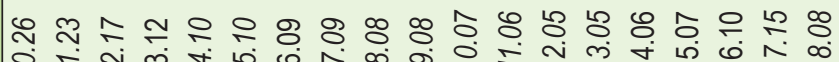

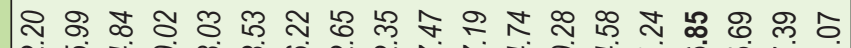

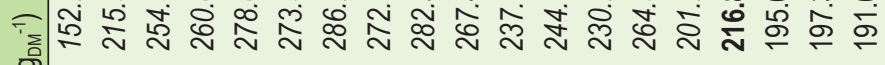

क

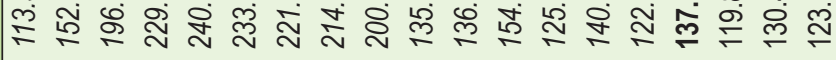

나유

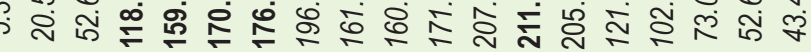

ก ก ส ป่

可

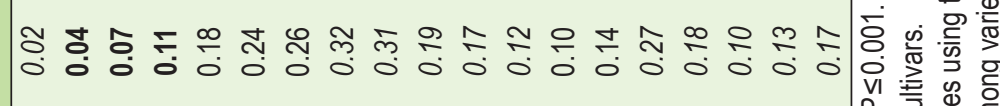

* * * * 萎菜辛

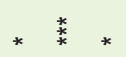

*

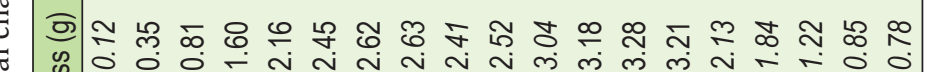




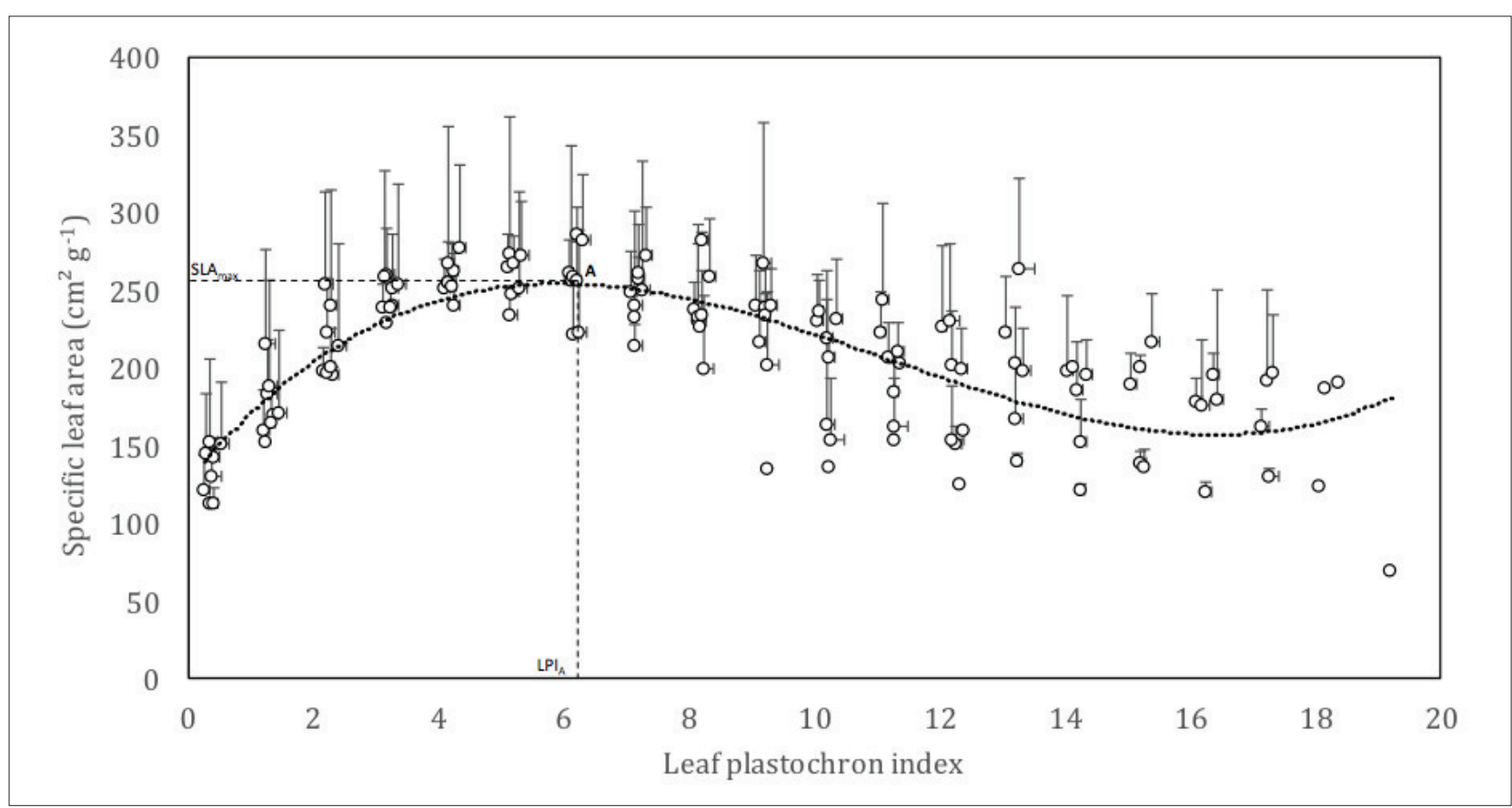

FIGURE 3. Relationship between leaf plastochron index (LPI) and specific leaf area (SLA). This relationship was established on cultivar means. Abbreviations: $\mathrm{SLA}_{\max }=$ maximal specific leaf area; $\mathrm{LPI}_{\mathrm{A}}=\mathrm{LPI}$ for leaf with maximal SLA.

tions, $K$ to the number of groups (cultivars), $R$ to the mean overall rank, and $R_{i}$ to the mean rank for group $i$.

Relationships among traits were tested using linear correlations (Pearson's test, $r_{p}$ ) based on genotypic means.

\section{Results}

\section{Determination of the first mature leaf}

The first mature leaf was determined for each cultivar. For each leaf, leaf area was measured, and LPI and SLA were calculated. The relationships between LPI, LA and SLA were plotted for each cultivar. The relationship between LA and LPI was presented in Figure 2a for 'Corabel ${ }^{\circledR '}$ (black dots) and 'Pauetet' (white dots). LA of 'Pauetet' increased up to LPI 8, became stable until LPI 12 , and decreased slowly to LPI 18. LA of 'Corabel ${ }^{\circledR '}$ ' seemed to have two growth phases, the first one between LPI 1 to 6 and the second between LPI 8 to 12 . 'Corabel ${ }^{\circledR '}$ cultivar also showed a rapid decrease of LA, from LPI 14 to LPI 18. Significant differences among cultivars for Leaf Fresh Mass, Leaf Dry Mass and LA were observed (Table 2). 'Tonda Pacifica' and 'Corabel ${ }^{\circledR '}$ cultivars had always the highest values of Leaf Fresh Mass, Leaf Dry Mass, and LA, when a cultivar effect was observed. Whatever the foliar index (FI), no cultivar effect was evidenced for SLA in the experiment, except for FI 16 (Table 2). The leaf with a maximal and stable SLA was observed when LPI ranged between 6 and 8 for 'Pauetet' and 'Corabel ${ }^{\circledR}$ ' cultivars, as represented in Figure $2 b$. The relationship between LPI and SLA was fitted, based on the cultivar mean (Figure 3), showing that the stable SLA over the 8 cultivars tested ranged from LPI 5 to LPI 7. This observation indicated the position of the first mature leaf. In the experiment and for the 8 cultivars tested, this leaf ranged between the sixth and the eighth leaves after the first leaf just exceeding $20 \mathrm{~mm}$ (FI 6-FI 8) (Table 2).

\section{Growth kinetics of the plants}

Between March $13^{\text {th }}$ and May 27th 2019 , few significant differences in stem length were observed (Figure 4a). When a significant difference between cultivars was evidenced, 'Corabel ${ }^{\circledR '}$ cultivar has always showed the highest values of stem length, and 'Sacajawea' cultivar showed the lowest values of stem length. The same trend was observed from June $5^{\text {th }}$ to July $23^{\text {th }}, 2019$, when 'Corabel ${ }^{\circledR \prime}$ ' and 'Tonda Pacifica' cultivars had the highest stem length and 'Sacajawea' the lowest (Figure 4b). Whatever the date of measurement considered, a significant cultivar effect was evidenced for the basal diameter during both first measurement period (Figure 4c) and second measurement phase (Figure 4d). 'Corabel ${ }^{\circledR '}$ and 'Pauetet' cultivars had always shown the highest values of diameters, while 'Santiam' and 'Tonda Pacifica' cultivars had the lowest significant diameters. The other cultivars tested, 'Ennis', 'Jefferson', 'Sacajawea', and 'Yamhill', seemed to be intermediate in terms of diameter value during the experiment. At stem level and over the experiment, the hazelnut cultivars produced between 0.10 and 0.20 leaves per day under greenhouse growing conditions.

\section{Biomass partitioning}

The biomass partitioning among compartments was evaluated (Figure 5). The results were expressed as dry biomass $\left(\mathrm{g}_{\mathrm{DM}}\right)$. It was observed that the root system represented approximately $35 \%$ of the total dry mass of the young tree. The other $65 \%$ were divided into three compartments (Leaves, Trunk, and Stems). This partitioning varied among cultivars, for which the lowest values for the root system proportion were observed for 'Pauetet' $(26.86 \pm 7.6 \%)$ and the highest values were shown for 'Ennis' cultivar $(43.70 \pm 9.7 \%)$. 'Ennis' cultivar had significantly higher root dry mass than other cultivars studied, while the 'Pauetet' cultivar showed a significantly lower root dry mass than other cultivars $(F=3.682, P=0.005)$ (Figure $5 a)$. In terms of dry woody biomass (stem and trunk), 'Pauetet' showed the highest wood dry mass (51.52 $\pm 8.19 \%)$ and 'Santiam' showed the lowest woody dry mass $(37.29 \pm 2.33 \%)$ compared to other cultivars $(K W=20.786, P=0.0041)$. The foliar dry mass varied significantly among cultivars $(K W=19.126, P=0.0078)$. 


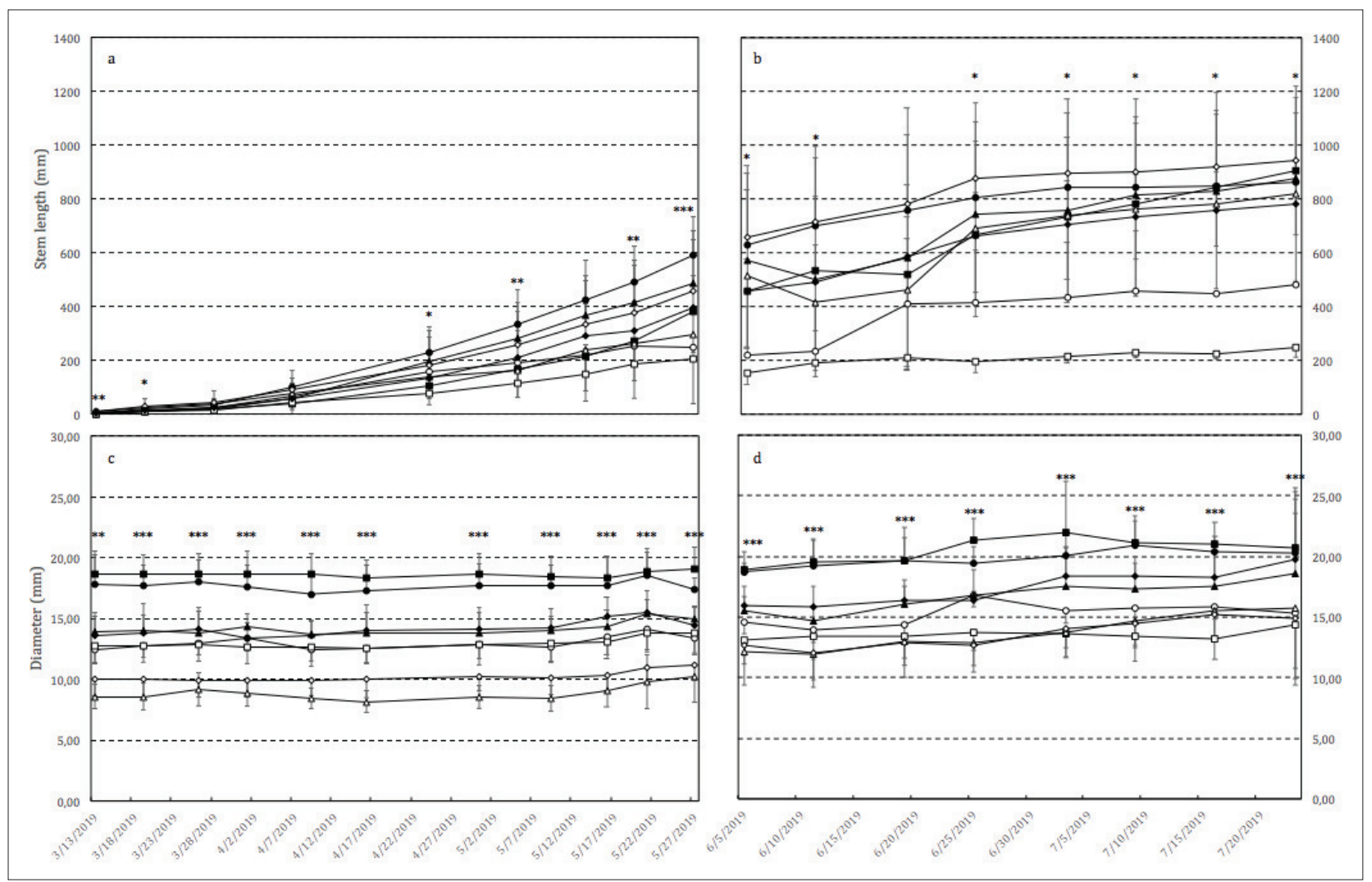

FigURE 4. Temporal evolution of stem height (a, b) and basal diameter (c, d) of eight hazelnut cultivars. Caption: 'Yamhill' ( $\bullet$ ), 'Tonda Pacifica' $(\diamond)$, 'Corabel ${ }^{\circledR \prime}(\boldsymbol{O})$, 'Ennis' $(\bigcirc)$, 'Sacajawea' $(\square)$, 'Pauetet' $(\square)$, 'Jefferson' $(\boldsymbol{\Delta})$, and 'Santiam' $\triangle$ ). Means are presented with their standard error. Levels of significance: ns: $P>0.05$; $: P \leq 0.05 ; * *: P \leq 0.01$; ***: $P \leq 0.001$. Plots a and c were built with data collected from March $13^{\text {th }}$ to May $27^{\text {th }}, 2019$ on 10 repetitions per cultivar, and plots b and d were obtained with data measured from June $6^{\text {th }}$ to July $23^{\text {rd }}, 2019$ on 5 repetitions per cultivar.
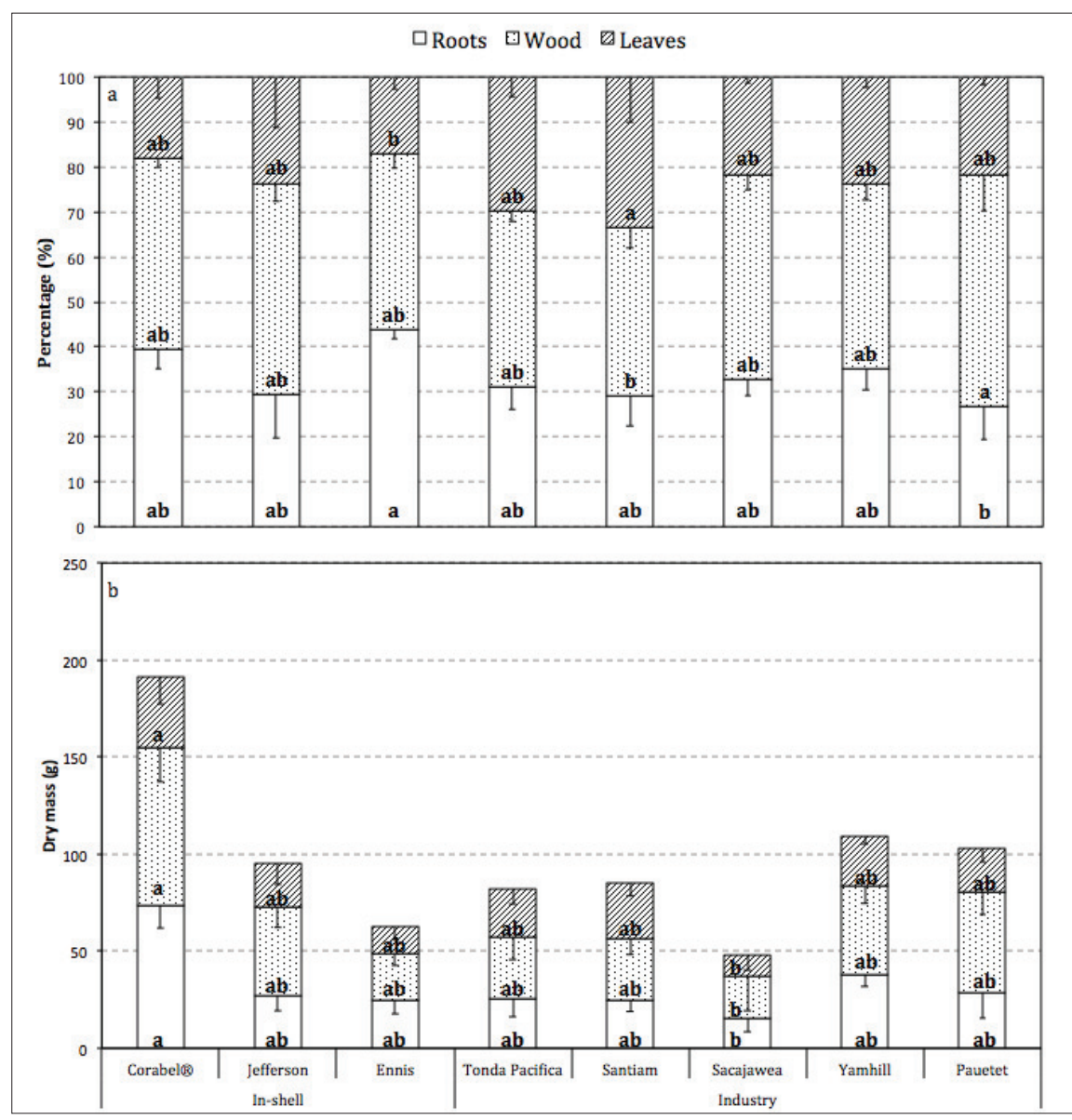

FIGURE 5. Biomass partitioning in roots $(\square)$, wood (四), and leaves (ㄴ) for each cultivar expressed as a percentage of total biomass (a) or in gram (b) of dry mass. Means are presented with their standard error. In each compartment (roots, wood, and leaves), a different letter indicates a statistical difference among cultivars. Levels of significance: ns: $P>0.05$; *: $P \leq 0.05$; **: $P \leq 0.01$; ***: $P \leq 0.001$. 
'Ennis' cultivar showed the lowest proportion of leaf dry mass $(17.05 \pm 11.25 \%)$ while the highest leaf dry mass proportion was observed for 'Santiam' cultivar (33.52 $\pm 4.51 \%)$.

When the biomass was expressed in $\mathrm{g}_{\mathrm{DM}}$ (Figure 5b), 'Corabel ${ }^{\circledR '}$ cultivar had the highest values of dry mass for each compartment, $73.86 \pm 12.19 \mathrm{~g}_{\mathrm{DM}}$ for the root system $(K W=22.218, P=0.00233), 81.34 \pm 17.96 \mathrm{~g}_{\mathrm{DM}}$ for the woody compartment $(K W=23.318, P=0.0015)$ and $117.06 \pm 29.13$ $\mathrm{g}_{\mathrm{DM}}$ for the foliar compartment $(F=3.434, P=0.00748)$. At the same time, 'Sacajawea' cultivar produced significantly lower root systems $\left(15.38 \pm 5.79 \mathrm{~g}_{\mathrm{DM}} ; K W=22.218, P=0.00233\right)$, woody dry mass $\left(21.62 \pm 8.59 \mathrm{~g}_{\mathrm{DM}} ; K W=23.318, P=0.0015\right)$ and foliar dry mass $\left(32.36 \pm 13.49 \mathrm{~g}_{\mathrm{DM}} ; F=3.434, P=0.00748\right)$ than other cultivars.

\section{Relationships among traits}

Linear relationships between variables were evaluated using Pearson linear coefficient correlation $\left(r_{p}\right)$ at different levels. Parts A and B of Table 3 showed the Pearson coefficients, among traits evaluated during the determination of the first mature leaf, and at the leaf level (Table $3 \mathrm{~A}$ ) and stem level (Table 3B). All leaf traits were significantly correlated themselves, except leaf dry mass and SLA $(0.17, n s)$. Positives and linear correlations between leaf area and leaf growth parameters (leaf length, leaf fresh, and leaf dry mass) were evidenced. At stem level (Table 3B), productivity parameters (growth and biomass traits) were highly correlated. The leaf parameters were correlated with the stem diameter. Only cumulative leaf width and cumulative leaf length were significantly correlated with stem length.

Correlations among traits evaluated in the second experiment were presented in part $\mathrm{C}$ of Table 3 . As observed at stem level, growth and biomass traits were positively and linearly correlated at the plant level. At the whole plant level, it was interesting to note that only foliar dry mass was significantly correlated with the $1^{\text {st }}$ mature leaf $\left(0.40,{ }^{* *}\right)$. Only leaf dry mass was positively correlated with the leaf area of the $1^{\text {st }}$ mature leaf $\left(0.86,{ }^{* * *}\right)$. Leaf area and SLA were negatively correlated $(-0.49, * *)$.

\section{Discussion}

\section{First mature leaf, leaf growth and morphology}

Numerous articles described the evaluation of leaf parameters under contrasted growing environments (Awada and Josiah, 2007; Catoni et al., 2015; Hampson et al., 1996; Kull and Niinemets, 1993; Marsal et al., 1997; Niinemets et al., 1998; Pasqualotto et al., 2018; Schulze and Küppers, 1979). These articles did not state the position of the leaf sample used for their experiments. Some chose to describe the leaf according to the leaf age (Schulze and Küppers, 1979), and some others, the leaf position in the canopy (Pasqualotto et al., 2018; Valentini et al., 2009). To our knowledge, the current study was the first to investigate the position of the first mature leaf in cultivated hazelnuts. For each of the eight cultivated cultivars of hazelnuts described, the first mature leaf was located at foliar index 7 , i.e., the first mature leaf was the seventh leaf on the stem, from the first leaf just exceeding $20 \mathrm{~mm}$, below the apex of the stem. In a fast-growing tree species, Populus sp., the first mature leaf was located at foliar index 17 (Marron et al., 2005; Monclus et al., 2005). In this study, the eight hazelnut cultivars, which were tested, showed similar relationships between SLA and LPI. But no cultivar effects were evidenced, as observed in Populus sp. (Marron et al., 2005; Monclus et al., 2005), hazelnut being a cultivated shrub with relatively slow growth and low final height (Germain and Sarraquigne, 2004), as compared with poplars, a fast-growing tree which can grow $3 \mathrm{~m}$ in one year and can grow up to $40 \mathrm{~m}$ at the end of its growth (Toillon, 2013).

A decrease of SLA was evidenced when the final leaf size was reached as already observed in poplar (Monclus et al., 2005). This decrease of SLA could be due to an adjustment of the cuticle thickness and secondary wall cell thickness (Monclus et al., 2005; Schumaker et al., 1997; Valentini et al., 2009), or to the mineral elements and photosynthetic assimilates retention during the leaf life (Marron et al., 2002; Monclus et al., 2005; Nelson and Isebrands, 1983).

The hazelnut cultivars of the present study produced between 0.10 and 0.20 leaves per day and the leaf area ranged from $54 \mathrm{~cm}^{2}$ to $117 \mathrm{~cm}^{2}$. These results were in accordance with the fact that hazelnut was not a fast-growing shrub. Indeed, leaf growth of fast-growing trees such as poplars, could vary from 0.14 to 0.52 leaves per day (Toillon et al., 2013a). The data observed in this study did not actually show the reality of hazelnut growth in an orchard or in a forest. Indeed, the growth was fostered in the semi-controlled growing conditions (greenhouse growth conditions). The leaf growth per day observed in uncontrolled conditions, could be lower than that calculated in this study. Moreover, this study focussed on eight $C$. avellana L. hazelnut cultivars. It could be interesting to study other species of Corylus genus, such as Corylus colurna, and to confirm these results at the level of Corylus genus.

\section{Growth and biomass productivity of young hazelnuts}

A low decrease of basal diameter (secondary growth) was observed at bud break. Basal diameter got back to its initial diameter one month after bud break. During this time, the carbon constituting the wood stock was remobilised to initiate the formation of new vegetative organs, as observed in peach and pistachio (Maurel et al., 2004; Millard and Grelet, 2010; Spann et al., 2008). Two months later, the plants showed an increase of secondary growth. Vegetative organs were fully functional, and the carbon assimilated was higher than the plant needed. Carbon was stored in the woody organs, as observed in beech (Bouriaud et al., 2004). Secondary growth was generally observed during summer from June to August, in the northern hemisphere. The tested cultivars seemed to have various growth strategies. 'Corabel ${ }^{\circledR}$ ' cultivar showed a rapid development of the aerial parts with a high stem growth during the first two months of measurements and a slower stem growth in June and July, while 'Tonda Pacifica' cultivar showed the opposite trend. These two cultivars seemed to have a strong vigour as shown by both high stem length growth, and trunk diameter. A cultivar, such as 'Sacajawea', showed the lowest values of stem height and trunk diameter. These results were in accordance with the cultivar description, in which 'Sacajawea' had vigour equivalent to $80 \%$ of 'Barcelona' vigour (Mehlenbacher et al., 2008). 'Barcelona' cultivar was yet less vigorous than 'Corabel ${ }^{\circledR \prime}$ (Germain and Sarraquigne, 2004).

'Ennis', 'Santiam', and 'Pauetet' cultivars did not show the same biomass partitioning as the five other cultivars. 'Ennis' cultivar had the biggest root system and the smallest foliar biomass. 'Ennis' plants, used in this study, showed a slow growth and were dwarfed compared to other cultivars. 'Ennis' cultivar was usually not considered a very vigorous tree (Hummer and Lagerstedt, 2002). Another possibility was that higher leaf biomass provided higher photosynthesis and 


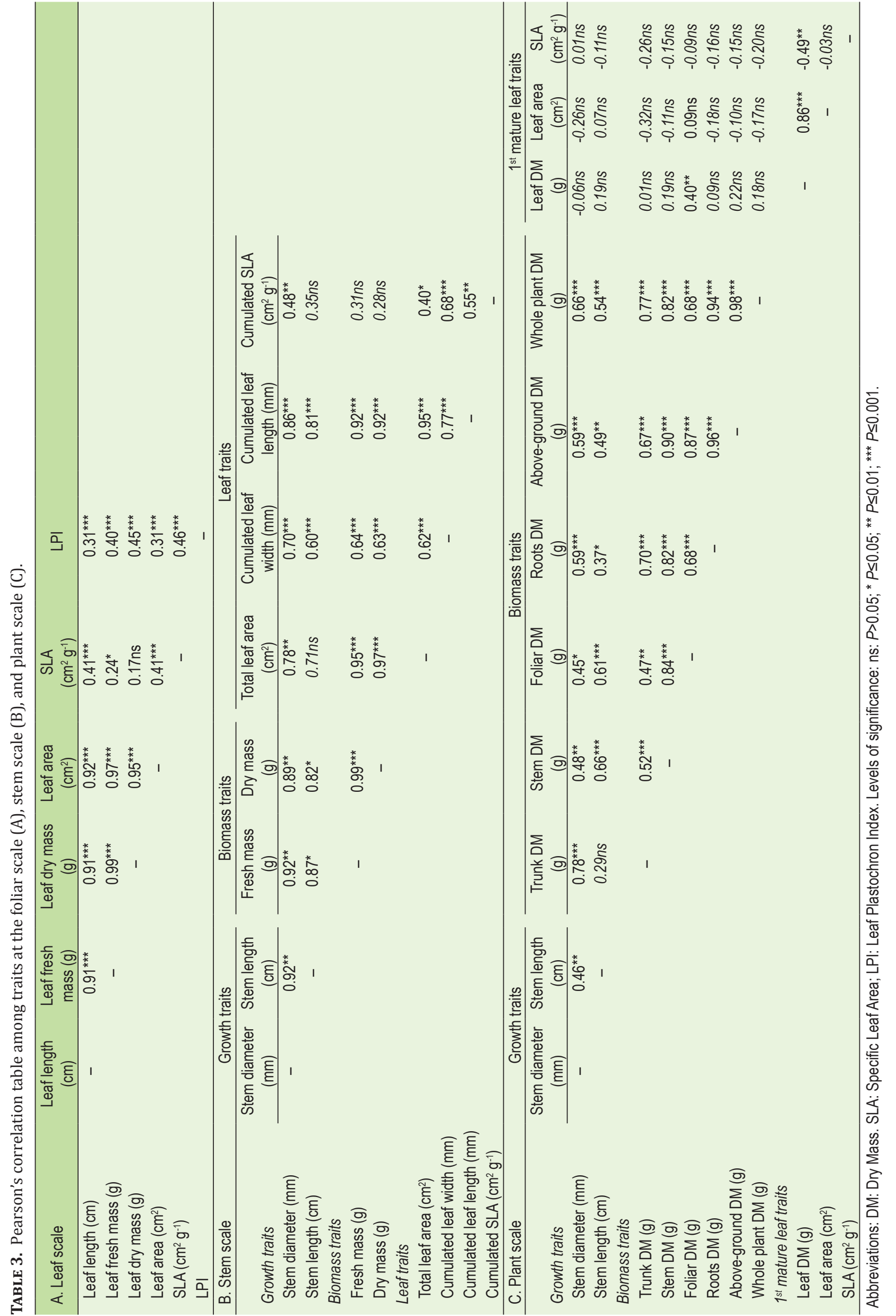


higher rates of water uptake. It was thus expected that leaf allocation decreased and root allocation increased, following the functional equilibrium model (Poorter and Nagel, 2000). 'Pauetet' cultivar had a smaller root compartment than all other cultivars. This data could be explained by the fact that 'Pauetet' plants were originated from cutting while all other cultivars were obtained by micro-cutting in vitro conditions. Indeed, the initial root system was smaller in 'Pauetet' cultivars. It was interesting to note that 'Santiam' cultivar had the lowest woody biomass and the highest foliar biomass. This cultivar was known to be a low vigorous tree (between $61 \%$ and $73.5 \%$ of 'Barcelona' vigour) and was concordant with our results (Mehlenbacher et al., 2007). 'Santiam' was an early cultivar, falling nuts 14 days earlier than 'Barcelona', i.e., in late August or beginning of September, in French growing conditions. 'Santiam' cultivar was the first cultivar to leaf bud break in our growing conditions. This early bud break gave time for the longest period of aerial growth and could partially explain the highest foliar biomass of 'Santiam', compared to other tested cultivars.

The mean proportion of the root system was 35\%, and the aerial part represented approximately $65 \%$ of the biomass partitioning. This data could change according to the physiological stage or the type of plant material studied (Poorter and Nagel, 2000). Our results were in accordance with those observed in young trees developing from seedlings, for which the mean partitioning was $68 \%$ for the above-ground part and 32\% for the root system (Poorter and Nagel, 2000). A recent study showed that root biomass of $C$. avellana L. seedlings represented $26 \%$ of their total dry biomass (Rostamikia et al., 2017). This data was lower than that observed in our study, but the plant material used was different. It seemed that plant origin, seedling or cutting propagation, could have a great influence on biomass distribution across plants compartments. The aerial biomass partitioning in leaves and stem compartments was similar to that observed in C. avellana L. seedlings (Rostamikia et al., 2017) but was the opposite of that reported for tree seedlings (Poorter and Nagel, 2000). This could be explained by the fact that hazelnut being not really a tree but a shrub in natural growth conditions, and our tested material did not come from seedlings.

\section{Relationships among traits}

Positives and linear correlations between stem diameter, stem length, and leaf area were evidenced in the experiment, as already observed in other shrub species, such as Salix sp. (Toillon et al., 2013b), or tree species such as Populus sp. (Toillon et al., 2013a). At foliar level, growth leaf parameters were correlated. Indeed, leaf length and width were good estimators of leaf area, as observed in other species (Keramatlou et al., 2015; Rouphael et al., 2010; Tsialtas et al., 2008). Opposite relationships between SLA and leaf area were observed in the present study. In the first experiment, SLA was positively correlated with LA, but not with leaf dry mass, suggesting that the thicker leaves indicated unshaded leaves. However, at the end of the experiment, SLA was uncorrelated with LA, but correlated with leaf dry mass, indicating that leaves were potentially shaded. Shadow could be due to the higher density of leaves for a same leaf area. It was observed in various species that the leaf shade degree influenced SLA (Catoni et al., 2015; Toillon, 2013). It was also evidenced that leaf dry mass was highly and linearly correlated to leaf area, suggesting good growth conditions in terms of nutrient availability, whatever the considered level. In this study, leaves with large areas were those with the highest weight. This would result in stable SLA and foliar index, whatever the tested cultivar.

\section{Conclusion}

This study showed a good stability of SLA according to LPI among the eight hazelnut cultivars tested. For the first time, the position of the first mature leaf in cultivated Corylus avellana L. cultivars, was evidenced. This leaf was the seventh leaf from the first leaf just exceeding $20 \mathrm{~mm}$ below the apex. The draining of reserves stored in the wood at the regrowth time, was clearly observed by reducing stem diameter during the first weeks of our study. The secondary growth appeared at least one month after the bud break, corresponding to the delay of leaf maturation in our study. New carbon atoms were then stored in the wood of the stem for plant growth and available carbon stock.

\section{Acknowledgments}

The authors would like to thank the Association Nationale des Producteurs de Noisettes and the Cooperative Unicoque, for their financial and technical support. This study was granted by FranceAgriMer project OptiVarNoisette, grant number 13317. The authors wish to thank Xavier Duchamp for his involvement in the greenhouse management and the plant growth management. The authors wish to thank Pr. Shawn Mehlenbacher from the Oregon State University for providing plant material. The authors also thank the four anonymous reviewers for their useful comments on the previous version of the manuscript. The authors also thank Mariane Hartridge for her reading of the different versions of this paper. The authors also thank Sylvie Maynard from CC-D3 de Beyrines company for her language review of a previous version of the manuscript. Finally, the authors would specifically thank Katia Bonne from Li-Cor Corporate for the loan of the LI 3050.

\section{Conflict of interest statement}

The authors declare that they have no conflict of interest.

\section{References}

Ade-Ademilua, O.E., Botha, C.E.J., and Strasser, R.J. (2005). A reevaluation of plastochron index determination in peas - A case for using leaflet length. South Afr. J. Bot. 71, 76-80. https://doi. org/10.1016/S0254-6299(15)30152-6.

Anil, S., Kurt, H., Akar, A., and Bulam Köse, C. (2016). Hazelnut culture in Turkey. Chron. Hortic. 56, 30-35.

Awada, T., and Josiah, S. (2007). Physiological responses of four hazelnut hybrids to water availability in Nebraska. Gt. Plains Res. J. Nat. Soc. Sci. 17, 193-202.

Begg, J.E., and Turner, N.C. (1976). Crop water deficits. In Advances in Agronomy (Elsevier), p. 161-217. https://doi.org/10.1016/S00652113(08)60555-6.

Bergougnoux, F., Germain, E., and Sarraquigne, J.P. (1978). Le Noisetier: Production et Culture (Limoges, France).

Bertamini, M., and Nedunchezhian, N. (2002). Leaf age effects on chlorophyll, Rubisco, photosynthetic electron transport activities and thylakoid membrane protein in field grown grapevine leaves. J. Plant Physiol. 159, 799-803. https://doi.org/10.1078/0176-16170597.

Botta, R., Molnar, T.J., Erdogan, V., Valentini, N., Torello Marinoni, D., and Mehlenbacher, S.A. (2019). Hazelnut (Corylus spp.) breeding. In Advances in Plant Breeding Strategies: Nut and Beverage Crops, 
J.M. Al-Khayri, S.M. Jain, and D.V. Johnson, eds. (Cham: Springer Int. Publishing), p. 157-219. https://doi.org/10.1007/978-3-03023112-5_6.

Bougeard, S., and Dray, S. (2018). Supervised Multiblock Analysis in $R$ with the ade4 package. J. Stat. Softw. 86. https://doi.org/10.18637/ jss.v086.i01.

Bouriaud, O., Bréda, N., Le Moguédec, G., and Nepveu, G. (2004). Modelling variability of wood density in beech as affected by ring age, radial growth and climate. Trees 18, 264-276. https://doi. org/10.1007/s00468-003-0303-x.

Catoni, R., Granata, M.U., Sartori, F., Varone, L., and Gratani, L. (2015). Corylus avellana responsiveness to light variations: Morphological, anatomical, and physiological leaf trait plasticity. Photosynthetica 53, 35-46. https://doi.org/10.1007/s11099-015-0078-5.

Chessel, D., Dufour, A.-B., and Thioulouse, J. (2004). The ade4 package - I : One-table methods. R News 4, 5-10.

Dray, S., Dufour, A.B., and Chessel, D. (2007). The ade4 Package II: Two-table and K-table methods. R News 7, 47-52.

Erickson, R.O., and Michelini, F.J. (1957). The Plastochron Index. Am. J. Bot. 44, 297-305. https://doi.org/10.1002/j.1537-2197.1957. tb10544.x.

Farquhar, G., Schulze, E., and Kuppers, M. (1980). Responses to humidity by stomata of Nicotiana glauca L. and Corylus avellana L. are consistent with the optimization of carbon dioxide uptake with respect to water loss. Funct. Plant Biol. 7, 315. htpps://doi. org/10.1071/PP9800315.

Fischer, R.A., and Turner, N.C. (1978). Plant productivity in the arid and semiarid zones. Annu. Rev. Plant Physiol. 29, 277-317. https:// doi.org/10.1146/annurev.pp.29.060178.001425.

Food and Agriculture Organisation of the United Nations (2020). FAOSTAT.

Germain, E., and Sarraquigne, J.-P. (2004). Le Noisetier (Paris, France: Centre Technique Interprofessionnel des Fruits et Légumes).

Hammel, H.T. (1968). Measurement of turgor pressure and its gradient in the phloem of oak. Plant Physiol. 43, 1042-1048. https:// doi.org/10.1104/pp.43.7.1042.

Hampson, C.R., Azarenko, A.N., and Potter, J.R. (1996). Photosynthetic rate, flowering, and yield component alteration in hazelnut in response to different light environments. J. Am. Soc. Hortic. Sci. 121, 1103-1111. https://doi.org/10.21273/JASHS.121.6.1103.

Hummer, K.E., and Lagerstedt, H.B. (2002). 'Ennis' hazelnut. J. Am. Pomol. Soc. 56, 194-196.

Ishida, A., Yazaki, K., and Hoe, A.L. (2005). Ontogenetic transition of leaf physiology and anatomy from seedlings to mature trees of a rain forest pioneer tree, Macaranga gigantea. Tree Physiol. 25, 513-522. https://doi.org/10.1093/treephys/25.5.513.

Kassambara, A., and Mundt, F. (2017). factoextra: Extract and visualize the results of multivariate data analyses. https://cran.rproject.org/web/packages/factoextra/index.html.

Keramatlou, I., Sharifani, M., Sabouri, H., Alizadeh, M., and Kamkar, B. (2015). A simple linear model for leaf area estimation in Persian walnut (Juglans regia L.). Sci. Hortic. 184, 36-39. https://doi. org/10.1016/j.scienta.2014.12.017.

Kull, O., and Niinemets, U. (1993). Variations in leaf morphometry and nitrogen concentration in Betula pendula Roth., Corylus avellana L. and Lonicera xylosteum L. Tree Physiol. 12, 311-318. https://doi. org/10.1093/treephys/12.3.311.

Lagerstedt, H.B. (1980). 'Ennis' and 'Butler' filberts. HortScience 15, 833-835.
Lê, S., Josse, J., and Husson, F. (2008). FactoMineR : An $R$ Package for Multivariate Analysis. J. Stat. Softw. 25. https://doi.org/10.18637/ jss.v025.i01.

Marron, N., Delay, D., Petit, J.-M., Dreyer, E., Kahlem, G., Delmotte, F.M., and Brignolas, F. (2002). Physiological traits of two Populus $\times$ euramericana clones, Luisa Avanzo and Dorskamp, during a water stress and re-watering cycle. Tree Physiol. 22, 849-858. https://doi. org/10.1093/treephys/22.12.849.

Marron, N., Villar, M., Dreyer, E., Delay, D., Boudouresque, E., Petit, J.-M., Delmotte, F.M., Guehl, J.-M., and Brignolas, F. (2005). Diversity of leaf traits related to productivity in 31 Populus deltoides $\times$ Populus nigra clones. Tree Physiol. 25, 425-435. https://doi.org/10.1093/ treephys/25.4.425.

Marsal, J., Girona, J., and Mata, M. (1997). Leaf water relation parameters in almond compared to hazelnut trees during a deficit irrigation period. J. Am. Soc. Hortic. Sci. 122, 582-587. https://doi. org/10.21273/JASHS.122.4.582.

Maurel, K., Leite, G.B., Bonhomme, M., Guilliot, A., Rageau, R., Pétel, G., and Sakr, S. (2004). Trophic control of bud break in peach (Prunus persica) trees: A possible role of hexoses. Tree Physiol. 24, 579-588. https://doi.org/10.1093/treephys/24.5.579.

Mehlenbacher, S.A., and Smith, D.C. (1995). Inheritance of the Cutleaf Trait in hazelnut. HortScience 30, 611-612. https://doi. org/10.21273/HORTSCI.30.3.611.

Mehlenbacher, S.A., Azarenko, A.N., Smith, D.C., and McCluskey, R. (2007). 'Santiam' hazelnut. HortScience 42, 715-717. https://doi. org/10.21273/HORTSCI.42.3.715.

Mehlenbacher, S.A., Smith, D.C., and McCluskey, R.L. (2008). 'Sacajawea' hazelnut. HortScience 43, 255-257. https://doi. org/10.21273/HORTSCI.43.1.255.

Mehlenbacher, S.A., Smith, D.C., and McCluskey, R.L. (2009). 'Yamhill' hazelnut. HortScience 44, 845-847. https://doi.org/10.21273/ HORTSCI.44.3.845.

Mehlenbacher, S.A., Smith, D.C., and McCluskey, R.L. (2011a). 'Jefferson' hazelnut. HortScience 46, 662-664. https://doi. org/10.21273/HORTSCI.46.4.662.

Mehlenbacher, S.A., Smith, D.C., McCluskey, R.L., and Thompson, M.M. (2011b). 'Tonda Pacifica' hazelnut. HortScience 46, 505-508. https://doi.org/10.21273/HORTSCI.46.3.505.

Mehlenbacher, S.A., Smith, D.C., and McCluskey, R.L. (2018). 'Burgundy Lace' ornamental hazelnut. HortScience 53, 387-390. https://doi.org/10.21273/HORTSCI12623-17.

Mendiburu, F. (2010). Agricolae: Statistical Procedures for Agricultural Research. R Package v. 1, p. 1-8.

Millard, P., and Grelet, G. (2010). Nitrogen storage and remobilization by trees: Ecophysiological relevance in a changing world. Tree Physiol. 30, 1083-1095. https://doi.org/10.1093/treephys/tpq042.

Monclus, R., Dreyer, E., Delmotte, F.M., Villar, M., Delay, D., Boudouresque, E., Petit, J.-M., Marron, N., Bréchet, C., and Brignolas, F. (2005). Productivity, leaf traits and carbon isotope discrimination in 29 Populus deltoides $\times$ P. nigra clones. New Phytol. 167, 53-62. https://doi.org/10.1111/j.1469-8137.2005.01407.x.

Nelson, N., and Isebrands, J. (1983). Late-season photosynthesis and photosynthate distribution in an intensively-cultured Populus nigra × laurifolia clone. Photosynthetica 17, 537-549.

Niinemets, Ü., Kull, O., and Tenhunen, J.D. (1998). An analysis of light effects on foliar morphology, physiology, and light interception in temperate deciduous woody species of contrasting shade tolerance. Tree Physiol. 18, 681-696. https://doi.org/10.1093/ treephys/18.10.681. 
Pallardy, S.G. (2008). Ch. 12 - Transpiration and plant water balance. In Physiology of Woody Plants ( $3^{\text {rd }}$ edn.), S.G. Pallardy, ed. (San Diego: Academic Press), p. 325-366.

Pasqualotto, G., Carraro, V., Conati, S., Chloé, C., Salaün, G., Mercadal, M., Vacca, A., Castagna, A., Utili, G., Lisperguer, M.J., et al. (2018). Stomatal sensitivity in Corylus avellana (L.): First analysis from a global dataset. Acta Hortic. 1226, 181-188. https://doi. org/10.17660/ActaHortic.2018.1226.27.

Poorter, H., and Nagel, O. (2000). The role of biomass allocation in the growth response of plants to different levels of light, $\mathrm{CO}_{2}$, nutrients and water: A quantitative review. Funct. Plant Biol. 27, 1191. https:// doi.org/10.1071/PP99173_CO.

R Core Team (2019). R: A Language and Environment for Statistical Computing (Vienna, Austria: R Foundation for Statistical Computing).

Rostamikia, Y., Kouchaksaraei, M.T., Asgharzadeh, A., and Rahmani, A. (2017). Biomass allocation, leaf gas exchange and nutrient uptake of hazelnut seedlings in response to Trichoderma harzianum and Glomus intraradices inoculation. J. For. Sci. 63, 219-226. https://doi. org/10.17221/99/2016-JFS.

Rouphael, Y., Mouneimne, A.H., Ismail, A., Mendoza-De Gyves, E. Rivera, C.M., and Colla, G. (2010). Modeling individual leaf area of rose (Rosa hybrida $\mathrm{L}$.) based on leaf length and width measurement. Photosynthetica 48, 9-15. https://doi.org/10.1007/s11099-0100003-x.

Scholander, P.F., Hammel, H.T., Hemmingsen, E.A., and Bradstreet, E.D. (1964). Hydrostatic pressure and osmotic potential in leaves of mangroves and some other plants. Proc. Natl. Acad. Sci. 52, 119-125. https://doi.org/ 10.1073/pnas.52.1.119.

Scholander, P.F., Bradstreet, E.D., Hemmingsen, E.A., and Hammel, H.T. (1965). Sap pressure in vascular plants: Negative hydrostatic pressure can be measured in plants. Science 148, 339-346. https:// doi.org/10.1126/science.148.3668.339.

Schulze, E.-D., and Küppers, M. (1979). Short-term and long-term effects of plant water deficits on stomatal response to humidity in Corylus avellana L. Planta 146, 319-326. https://doi.org/10.1007/ BF00387804.

Schumaker, M.A., Bassman, J.H., Robberecht, R., and Radamaker, G.K. (1997). Growth, leaf anatomy, and physiology of Populus clones in response to solar ultraviolet-B radiation. Tree Physiol. 17, 617-626. https://doi.org/10.1093/treephys/17.10.617.

Spann, T.M., Beede, R.H., and DeJong, T.M. (2008). Seasonal carbohydrate storage and mobilization in bearing and non-bearing pistachio (Pistacia vera) trees. Tree Physiol. 28, 207-213. https:// doi.org/10.1093/treephys/28.2.207.

Toillon, J. (2013). Genetic variability and plasticity of resourceuse efficiency (water and nitrogen) in Salicaceae grown under short-rotation forestry and short-rotation coppice (Université de Lorraine).

Toillon, J., Fichot, R., Dallé, E., Berthelot, A., Brignolas, F., and Marron, N. (2013a). Planting density affects growth and water-use efficiency depending on site in Populus deltoides $\times$ P. nigra. For. Ecol. Mgt. 304, 345-354. https://doi.org/10.1016/j.foreco.2013.05.017.

Toillon, J., Rollin, B., Dallé, E., Feinard-Duranceau, M., Bastien, J.-C., Brignolas, F., and Marron, N. (2013b). Variability and plasticity of productivity, water-use efficiency, and nitrogen exportation rate in Salix short rotation coppice. Biomass Bioenergy 56, 392-404. https://doi.org/10.1016/j.biombioe.2013.05.017.

Tsialtas, J., Koundouras, S., and Zioziou, E. (2008). Leaf area estimation by simple measurements and evaluation of leaf area prediction models in Cabernet-Sauvignon grapevine leaves. Photosynthetica 46, 452-456. https://doi.org/10.1007/s11099-008-0077-x.
Tyree, M.T., and Hammel, H.T. (1972). The measurement of the turgor pressure and the water relations of plants by the pressurebomb technique. J. Exp. Bot. 23, 267-282. https://doi.org/10.1093/ $\mathrm{jxb} / 23.1 .267$

Valentini, N., Caviglione, M., Ponso, A., Lovisolo, C., and Me, G. (2009). Physiological aspects of hazelnut trees grown in different training systems. Acta Hortic. 845, 233-238. https://doi.org/10.17660/ ActaHortic.2009.845.32.

Venables, W.N., and Ripley, B.D. (2002). Modern Applied Statistics with S (New York: Springer).

Received: Oct. 9, 2020

Accepted: Jan. 29, 2021

Addresses of authors:

Julien Toillon ${ }^{1, *}$, Alane Paradinas ${ }^{1}$ and Maud Thomas ${ }^{2}$

${ }^{1}$ Association Nationale des Producteurs de Noisettes

(ANPN), Louberie, F-47290 Cancon, France

2 SCA Unicoque, Louberie, F-47290 Cancon, France

* Corresponding author; E-mail: jtoillon@anpn.eu 